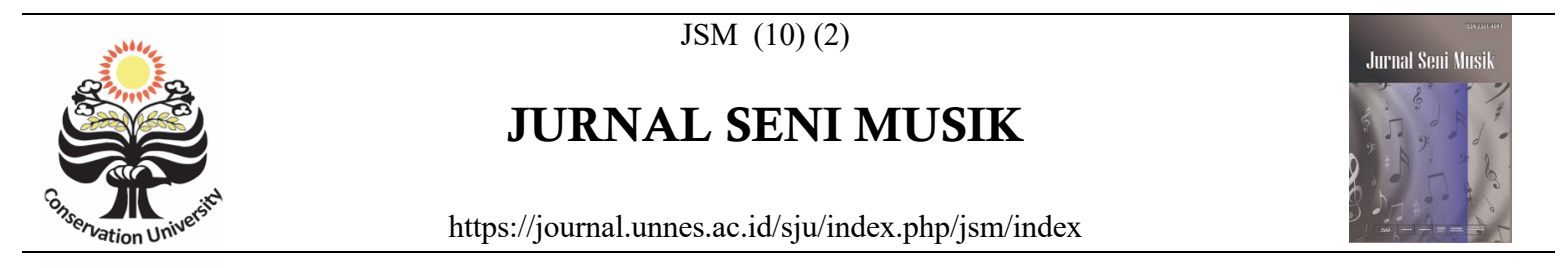

\title{
Creating Process of Composition Of The "Kulino" Musical Drama At Theater Aura Indonesia
}

Najwa Leonita Darussalam

Universitas Negeri Semarang, Indonesia

Joko Wiyoso ${ }^{\varpi 1}$

Universitas Negeri Semarang, Indonesia

Article Info

Abstract

Submitted : May, 2021

Revised : November,2021

Accepted:December,2021

Music for the Aura Theater is not only a supporter of the presentation of the show, but also as a medium for conveying the core story in a performance that is packaged in the form of songs and becomes part of the storyline. This makes researchers interested in the process of creating songs in their musical dramas. This study aims to identify and describe the process of creating compositions

Keywords: music, music composition, musical drama for musical drama songs in Kulino scripts at the Aura Indonesia Theater performance. This study uses a qualitative descriptive method that produces descriptive data. The research location is in the center of theatrical activities of Theater Aura Indonesia with data sources from the chairman as well as the director of Kulino performances and composers. Data were collected by using observation, interview, and documentation techniques. The data analysis technique used in this study is an interactive model whose elements include data reduction, data presentation, and conclusions. The results showed that in the process of creating the composition of the Kulino musical drama song through stages (1) script review, namely the activities of appreciating, reviewing, discussing, or reviewing all the elements contained in the script to be worked on (2) observation, namely the stages carried out by the composer. to get musical inspiration which is then illustrated in the form of rough notes (3) pouring, namely pouring rough notes from observations into the form of musical compositions (4) embodiment, namely redeveloping the finished song by adding other musical instruments, namely keyboard, guitar melody, violin, cello, drum, bass, flute, and saxophone (5) presentation, in which the composer presents the finished song to the director and assistant director.

\footnotetext{
$\triangle$ Corresponding Author:

Email : jokowiyoso1962@mail.unnes.ac.id
} 


\section{INTRODUCTION}

Music is sound that is arranged in such a way as to produce a beautiful unity. As it is said that music is an idea or idea that is poured in the form of sounds and has various kinds of elements including melody, rhythmic, and harmony with the idea, nature, and color of sound as supporting elements (Syahbandi, Mering, \& Silaban, nd)

Music can affect human emotions as stated by (Shaleha, 2019) in his article on the psychology of music saying that listening to classical music after experiencing a stress can calm emotions more than listening to heavy metal songs or just sitting in silence. This relates to one of John Cage's works in 1951, entitled "4.33" which had raised many questions and worries to the point of shocking the music world because in his performance, John Cage did nothing and only faced the piano and the scores until the show ended. This shows that music is space and time where the time signature is space, and rhythmic beats are a symbol of time. This is one of the factors where music in its development is not only presented in the complete form of the music itself, but can be collaborated with the performances of other branches of art. One of them is that it can be collaborated with performing arts such as theater. Theater music is music that plays a role in setting a scene and building an atmosphere in a scene (Aprilian, 2017).

Theater Aura is a community in the field of theater arts, led by Risang Dhanarsantika Putra Sofana, a student at the Faculty of Law, Universitas Negeri Semarang. Theater Aura was established in 2018, but already has various brilliant achievements, one of which is in the 2019 Central Java Theater Festival (FTJT). Aura Theater managed to get the best presenter and the best main actor, 1st place at the Siti Nurbaya Festival in Jakarta. In addition to excelling in the theatre, Aura theater also developed other arts such as cinematography which also won the award for Best Story Idea Champion at the Brebes Regency General Level, Short Films Festival 2019 Winner, 3rd Place
Peksiminas in Yogyakarta in 2019, 1st Place Peksimida for the Special Capital Region of Jakarta in 2018 and succeeded in entering the five best "SIN" short films at the General level in Indonesia, which was held by Falcon Pictures in 2019. In its production, Teater Aura tends to doing musical drama scripts.

Theater is a literary work created to be performed in front of the public (Suryanto, Waluyo, \& Suyitno, 2016). Apart from being a medium of entertainment, theater performances are also used as a messenger with language as the medium.

Music in theatrical performances certainly has a very important function where the music can strengthen the scene. Music has a very important role in theatrical performances. The roles of music in theater include, the first as opening music. Opening music is music that can attract the attention of the audience because it serves as a notification that the show is about to start. Theatrical music has a role as closing music which serves as a marker that the show has finished. The role of music in the next theater is as a turn of act music. Act change music is very important in theatrical performances because this music serves to maintain the emotional stability of the audience in bringing the atmosphere to the next stage. The role of music in the next theater performance is as illustration music. Illustrated music is music composed to express the heart of an actor. That is, illustrative music is supporting music for actors in playing a character. Furthermore, music in theater has a role as a soundtrack. This music is usually presented in the form of a song with lyrics whose theme is the main or main theme in the story. Furthermore, music has a role as music themesong. This music can bring several characters according to the theme of the scene in a story. The role of music in the next theater performance is as setting music. Setting music is music that aims to explain the place and time of an event. The above review explains that music is one of the factors that influence the success of a theatrical performance. 
Music in the performances of the Aura Theater seems not only to be used as a support for the presentation of the show as described above, but to use music as the whole core of the storyline which is packaged in the form of a song. Part of the storyline in the Kulino script is presented in the form of a song so that the dramatic plot that is built up in the performance of the Kulino musical drama is not only created from the interaction and character acts, but part of the storyline or dramatization is poured in the form of the song. The song that is part of the storyline in the Kulino script is a song that is presented in the form of music and vocals where some of the verses or lyrics are dialogues that are sung and are the core of the story so it can be said that the performance staged by Teater Aura is a musical drama performance.

Based on the results of initial observations, the researchers found that the musical drama song which is the core of the storyline in the Kulino script is found in the opening song, scene and ending song. The music contained in the Kulino script must of course be in accordance with the nuances and atmosphere in each scene so that there is a match between the music and the scene being played. This is certainly a very important part in a theatrical performance because in a theatrical performance it is not enough just to rely on the acting skills of an actor in playing the scene, but the emotions of the actor in playing the role will be stronger if it is followed by music that matches the atmosphere in the scene.

Music is an idea or ideas that are poured into sounds that produce harmony. According to (Kholid, 2016) music is a form of art that processes sounds and pauses as the main raw material, in which there are rhythmic patterns, melodies, tempos and other musical elements arranged in such a way as to produce harmony. Music is the processing of sound and pauses as the raw material. This means that in music it is not only about sound, but not pitch is a part of music. As in a composition, the pause is also music (Kholid, 2016).

Music in theater performances is an important factor in performances, because music in theater serves as a supporter in performances. Music in theater can build an actor's emotions and give a dramatic impression and build an atmosphere in the story. Theatrical music is music that strengthens a scene that explains the era, time, atmosphere, and certain circumstances (Prastyo, 2018), (Pardede, 2018). Music in theater plays a role in setting a scene and building the atmosphere in a scene. (Aprilian, 2017).

Every creator of a work of art has a different view in making a work. This of course has to do with how they work. The first thing that comes to mind is an idea or ideas. In an art creation, ideas or ideas can be obtained directly or indirectly. The idea or ideas can come from oneself, nature, or it can be from any sound that the creator hears. The creation of art has three elements, namely knowledge, activity, and method. Wafa (2020) said the same thing, that making music, begins with making sounds, mixing sounds and reproducing which is a cycle of making music.

Knowledge is all ideas and thoughts that exist in the mind of the creator. Activity is the activity of the creator in compiling the artistic creativity that is in his mind. While the method is a technique of a creator in realizing all the ideas and creativity that is in his mind in the form of works that are real and can be enjoyed (Aprilian, 2017). An artist must have the ability to process everything that is inside and outside himself, namely ideas or ideas resulting from reflection and appreciation to be further expressed in the form of works of art (Pramudya, 2019).

Musical composition is a musical idea and the combination of musical elements through knowledge, experience, taste, and aesthetics to present an original musical presentation. composition is the basic concept of making a musical work that processes time as space. This basic concept is a composer's initial idea or idea in writing a musical composition that makes it easier for the composer to help the composer take the next step, namely taking into account form, tension or tension, melody, rhythm, harmony, to achieve more detailed things (Manggala, 2015), (Nugraha, 2013). 
Musical drama is a performing arts role in collaboration with music, motion, dance and vocals. The dialogues in the script are performed in the form of songs and sung by actors who play the characters in the story. As stated by Devanti, (2018), a musical drama is a drama combined with other arts such as dance and music that are packaged in such a way as to form an interesting choreography.

\section{METHOD}

This study uses a descriptive qualitative approach, which is a research procedure that produces descriptive data in the form of words from the perpetrators of the activities observed.

Based on the research objectives, the data will be obtained from people who know, are related and actors in the activity, namely the director and composer in the Kulino script itself. The object of research studied in this study is Teater Aura Indonesia.

Data collection techniques are observation, documentation, and interviews. Margono (2003: 158), observation is surveillance and recording systematically to the symptoms appeared on the object of this research. The data collection techniques used in this study were observation techniques, interview techniques and document study techniques.

$$
\text { Researchers }
$$
systematically compiled data obtained from observations, interviews and other data collected using interactive data analysis techniques whose elements include data collection, data reduction, data presentation, and conclusions. Researchers used source triangulation as a data validity technique.

\section{RESULTS AND DISCUSSIONS}

At first the Aura Indonesia theater had the name Aura Semarang theater, this was because at that time this theater was just starting out and it was likely to work a lot in the city of Semarang, but as the process progressed, it turned out that enthusiasts to join as members of the Aura theater came from other areas, such as
Yogyakarta, Bandung, Jakarta, Brebes, Tegal, Surabaya and Bali. So that on December 31, 2019, the Aura theater changed its name to Teater Aura Indonesia. Theater Aura Indonesia has a meaning which includes prayer, history, characteristics, hopes and philosophical meanings. Namely "AURA" the founders wished that the Aura theater would become a large theater capable of providing color and freshness following the development of the dynamics of society in each of their works. "AURA" is also taken from the name of the boarding house of one of the founders of the Aura theater, whose name is Aura.

On March 14, 2020, Teater Aura Indonesia staged a musical drama performance with the title Kulino. The Kulino manuscript is a script created by Risang Dhanarsantika Putra Sofana. This manuscript tells about the myth about the prohibition of marriage between Javanese and Balinese. The myth is that if the two people from these two islands are united in marriage, they will only harm themselves. This Kulino script tells the story of a pair of lovers who ignore the existing myths, they keep fighting for their love until finally death separates them both.

The musical compositions of Aura Theater are played by various musical instruments including guitar, bass, keyboard, violin, cello, saxophone, flute, drums and vocals. The composer as well as the arranger who composes and arranges the musical compositions in the performance of the culino play at Teater Aura Indonesia is Anik Prabowo. Aura theater musical compositions are the work of Aura theater members themselves.

The performance of the Kulino script by Teater Aura is handled with different musical nuances in each scene. This is done based on the atmosphere contained in the story. There are five complete songs by Teater Aura which are performed in Kulino scripts, including the songs Jumpa, Segitiga, Arti Cinta, Bumi Manusia and Fiksi Terbiasa. The lyrics in the song that was staged were a description of the story in the Kulino script. This is so 
that the audience gets an imagination or picture of what will happen in the story.

The cultivation of Aura theater music is made like a musical drama. The songs are divided first, namely the opening song, dialogue song, scene song, and ending song. In making the opening music, the composer is given the freedom to be creative, then the composer makes the opening music with the ideas and concepts that have been thought out. There are five stages carried out by composers in creating musical compositions for Kulino musical dramas.

The first stage is the script review stage. Review of manuscripts can be interpreted as an activity of appreciating, reviewing, discussing, or examining all the elements contained in the manuscript. Review of the script is the stage that aims to understand the content of the story in the script. Composers need to understand the content of the story to find out the atmosphere contained in the story, so that the story and the atmosphere of the music played are appropriate. In the script review stage, the songs were distributed which consisted of opening songs, dialogue songs, scene music, transitional music, and ending songs. In song division, not all dialogues in the script are presented in the form of songs, but divisions are made again to determine which parts are presented in the form of regular dialogues and which parts are presented in the form of songs. For example, there are ten dialogues in the script, then eight dialogues are presented in the form of music, and the remaining two dialogues are presented in the form of ordinary dialogue but still accompanied by music. This determination must still be in accordance with the director's approval. An example of the division of spoken and sung dialogue is found in the song in scene four.

Kuni : "bagaimana bisa kau tega melakukan ini padaku kulin?" (song)

Kulin : "tidak istriku ini tak seperti yang kau bayangkan" (song)

Kuni : "apa kau sudah buta juga sekarang?" (song)
Kulin : "dengarkan aku dulu Kuni" (lagu) "aku bisa jelaskan" (normally dialogue)

Kuni : "bagaimana bisa kau mengelak. Sudah jelas kau memadu kasih dengan wanita lain saat aku tak di rumah" (normally dialogue).

The second stage is the observation stage. Observation is the stage that the composer does to get musical inspiration which is then described in the form of rough notes. At this stage, the composer explores by watching theatrical performances either live or through video. The composer also made observations by listening to songs to get musical inspiration. In addition, Anik Prabowo's empirical experience as a theater music composer is also part of the exploration. His journey since high school has been spent in the world of theater, whose focus is on making musical compositions, both songs and illustrations. After getting the musical descriptions, the composer pours the musical picture in the form of rough notes.

The third stage is the pouring stage. Pouring is pouring rough notes from observations into the form of musical compositions. The musical ideas or ideas used in making this music are purely from their own ideas and concepts. But there is one song with the title "Perkawinan" which is inspired by Nadin Amizah's song. In the process of creating music, the composer uses guitar and vocal instruments. Meanwhile, in the process of making songs from the dialogue in the script, the composer must really pay attention to the division of songs for men and women to determine the basic tone of the song. In making this dialogue song, the composer cuts some words or changes some words which of course does not change the essence of the dialogue. This is done because of the need for music. In changing the dialogue, you still have to get the director's approval. The fourth stage is the embodiment stage. The finished song was developed by adding other musical instruments, namely a keyboard, melodic guitar, violin, cello, drums, bass, flute, and saxophone. In developing or making this arrangement, the 
composer arranged the composition of the song with his partner. This is done to speed up the creation of musical compositions.

The making of musical compositions in this Kulino script took two weeks. Then this composition is still being reprocessed to develop the arrangement by including other musical instruments. Making this arrangement takes one and a half weeks or about twelve days. The total in the making of this musical composition is three and a half weeks or approximately twenty-four days.

The fifth stage is presentation. Presentation is the final stage in making this musical composition. The composer presents the finished song to the director and assistant director. In making dialogue songs, the song must really be in accordance with the director's wishes, then the composer prepares several choices of song compositions which are then presented to the director, and the director chooses one of the several sample songs given. In making scene songs, songs are adapted to the atmosphere in each scene, as well as ending songs.

The difficulty experienced by composers is determining the basic tone of the dialogue songs sung by female and male actors, because both have different vocal ranges, so the composer must be really observant in determining the basic notes in a song. The second difficulty experienced by composers is determining agreement with actors regarding the number of loops in the song, such as determining how many core loops and how many loops before moving on to the next dialogue. Because in fact the actors in this Aura theater performance are not among the theater children and not among the music children. Another difficulty is, this Kulino script is a romantic story that must feature two main actors, namely Kuni and Kulin, so that the musical composition has a romantic nuance with the same tone, so that the musical composition seems monotonous, it is a challenge for the composer in making music not monotonous so that the audience not saturated with monotonous music. The composer anticipates this by creating a different flow in scene two where in this scene there is a dialogue between Bapak and Kulin.

Joint rehearsals between the music team and actors are conducted three times a week. Before doing joint rehearsal with the actors, the music team did rehearsals alone without actors to make practice time more efficient. After the music is completely mature, then it is combined with the actor scenes. This process takes a long time because there must be chemistry between the musician and the actor to determine when the actor enters the stage, when the actor has a dialogue accompanied by music, when the actor starts the song, determines the agreement on the number of intro rounds, when the actor leaves the stage, when the actor should start and end. dialogue, as well as when actors leave the stage. The rehearsal process to unite the scene with the music is very difficult, especially since the actors who play the roles in this script are not people who come from musicians.

The actors who are taken in this performance are people who are selected from the casting results that are open to the public. In general, musicians or people who at least understand music at least sing, will have a different speed of understanding with people who are fairly new to music. Then for the number of actors and musicians is about 20 people and this also sometimes makes the practice longer because there are actors or musicians who come late, or even can't attend for some reason. In the process, this exercise is not done directly by playing the script as a whole. The director simplifies rehearsals with cut-to-cut rehearsals. The director also organizes rehearsals by dividing each scene. It means to ripen the opening music first, then after it's really cooked, go to the first scene, and so on. The practice process by dividing each scene is certainly not short, because the musicians and actors must be completely in sync. The exercises are repeated until these two factors, namely the musicians and actors, really understand the game. Therefore, the process of creating music is carried out in stages and in different ways for each composer (Syahbandi et al., n.d.). Music creation is 
processing everything that is inside and outside the composer, namely ideas or ideas which will then be expressed in the form of works of art (Pramudya, 2019).

Based on the results of the research, the music created by Teater Aura is music produced for a theatrical performance, so that the creation process is slightly different from the creation of musical compositions in general. In the process of creating music, the composer must go through the script review process first to understand the content contained in the story so that the composer can determine the musical atmosphere that fits the storyline. In addition, the script review also aims to divide the dialogue between sung and unsung dialogues. Composers make observations by watching existing theater performances and also through the empirical experience of composers who have lived in the theater world for a long time and get a musical picture that is poured in the form of rough notes.

The next step is pouring, which is making the composition until it is finished. The next step is embodiment. Embodiment is the refinement of a finished song. The composer makes several choices of song forms which will then be taken in the final step, namely presentation to the director and assistant director.

In music creation, composers are given the freedom to express their ideas and ideas in the form of music with various steps, as mentioned by Aprilian, (2017) that art creation has three elements, namely knowledge, activity and method. Usman (2020), said the same thing that making music, begins with making sounds, mixing sounds and reproducing which is a cycle of making music. In this case, there are five songs created by Teater Aura Indonesia along with an explanation.

The first song is the song Bumi Manusia, the song that was chosen as the opening song. The reason for the song Bumi Manusia used as the opening song is the lyric. The lyrics in the song Bumi Manusia have indeed been made as an introduction to the core of the whole story. This song is a description of human life which has its own characteristics and colors in life. In this song there is a code in every scene that will occur later. The lyrics in the song Bumi Manusia have the meaning that this script will tell the story of human life.

Humans live on earth just to act. The play in question is a play that has been written by God. In the song Bumi Manusia, the intro section is filled with guitar as the main accompaniment with a repeating rhythm pattern then flute is used as the main melody in the intro and cello, violin is only as a layer to add to the feel of the grandeur of the section, then in part 1 the song is only accompanied by guitar. so that it doesn't seem monotonous so that when you enter the song part 2, the cello, the violin as a conductor to the chorus so that the dynamic gradation in the song can be seen. In the first chorus, all musical instruments begin to enter, such as the saxophone, flute, violin, cello, keyboard, bass, guitar, and drums which indicate that the dynamics of the music are starting to rise. According to the composer, in the interlude, the flute and saxophone play the melody because these instruments have characters that give the impression of being majestic and luxurious. Then in the outro or coda section, the atmosphere of the music is made like an intro as a dynamic gradation, which is a marker that the opening song will be finished then followed by the music of the first scene in the Kulino script.

The second is the song "Jumpa". the song meets is placed after the song Bumi Manusia because technically, after delivering the prologue or synopsis of the story so that the audience understands the initial picture of the story, after that the audience must be introduced to the characters who will play in the story and introduce the characteristics of the characters. The lyrics in the song Jumpa describe love, affection, indecision and doubt, therefore the song Jumpa was made to convey a sense of love, affection, indecision, doubt and even the fear of trusting each other. The song Bumi Manusia explains about human life that is different from humans in general, and this is explained by the second song. Jumpa is sung by two main characters, namely Kulin 
and Kuni because this story will tell about the two of them later.

The song Jumpa is made very romantic and the progression is very simple, namely I - IV -V. Although the chords are simple, they are played with reversal chords, namely the reversal of G\#/E - A/E - B/E. These colors give a romantic impression. The musical instruments used are cello, violin, flute and saxophone. This melodic musical instrument further adds to the romantic impression. The dynamics of the song is played gently first, then at the end it gradually rises because it describes the happiness of the two of them.

The third song is the song Arti Cinta. This song is played in the wedding scene between Kulin and Kuni as an explanation of the wedding scene. This song is made with the lyrics of love, happiness, and there is sadness in it. Arti Cinta is the initial introduction to the big conflict, so in this song the storyline has started to get into the real problem. The meaning of the lyrics of this song is a song about marriage which has different meanings.

Although the guitar accompaniment pattern in the song has the same rhythm pattern, it doesn't seem monotonous because of the tone selection. Flute as the main melody in the song to add a romantic feel and the cello and violin only play long notes to show a calm or serene atmosphere. In this song, the composer deliberately did not add a saxophone and drums because the inclusion of these instruments will change the nuances of the music in the scene so that the atmosphere contained in the scene cannot be conveyed to the audience.

The fourth song is the song "Segitiga" which is a conflict scene song, so this song "Segitiga" is a conversation, debate, problem that is made up by the song. In terms of composition and genre, because the dialogue in this song is sung by women, the music played must have a sad and sad nuance. although at the end the tempo is faster. This song is made with the impression of a song that blames each other. This song is placed in the fourth scene with the aim that the audience understands why the problems in the story are getting bigger because this song is a manifestation of the emotions that have accumulated since the beginning of Kulin and Kuni's marriage.

The guitar is played in the intro as accompaniment with a small electric guitar melody. The reason given by the composer was that he didn't want to highlight the music to steal the audience's focus because in this scene there is a scene of Kuni crying. Then in the song part 1 only accompanied by guitar and keyboard to show a sad atmosphere so that the scene of Kuni crying, the music does not steal the audience's focus. Then in the second part of the song, sung by Kulin, the violin and cello are introduced so that the music is not monotonous, and the violin and cello are also included as a gradation of the dynamics of the song to get to the chorus. In the chorus, all the musical instruments start to play to show the raging atmosphere as a support for the scene where Kulin and Kuni are arguing.

Then in the song part 3 which is sung by Citra, the dynamics of the music decreases like the song in part 1 to show Citra's expression who is explaining to Kuni. Then, entering the final chorus, all the musical instruments began to enter to support the scene where Kulin and Citra were convincing Kuni of the misunderstanding that occurred.

The last song is "Fiksi Terbiasa", which is a continuation of the synopsis on the first song, Bumi Manusia. Fiksi Terbiasa is also contains the whole story from beginning to end. In the ending song, the theme of the music is the same as the opening music for the first reason, so as not to remove the theme from the plot presented. Then the second, the composer does not want to lose the impression of grandeur and luxury in the opening and closing songs.

\section{CONCLUSION}

Based on the results of research and discussion on the process of creating music in the Aura Indonesia Theater in the Kulino script, it can be concluded that the 
process of creating music at the Aura Indonesia theater is carried out through several stages, namely script review, observation, casting, embodiment and presentation. Review of the manuscript is reviewing and examining all the elements in the manuscript, observation is the search for ideas which are then written in the form of rough notes, casting is the pouring of ideas written in the form of rough notes from the results of observations into the form of song compositions, embodiment is a refinement of composition finished music which is then arranged to add more varied musical instruments, and presentation is presenting the finished song to the director and assistant director. In this case, there are 5 songs created by Teater Aura Indonesia, namely Bumi Manusia, Jumpa, Arti Cinta, Segitiga, and Fiksi Terbiasa.

\section{REFERENCES}

Aprilian, P. S. (2017). Proses Penciptaan Musik Teater Lungid pada Karya Leng. Institut Seni Indonesia Surakarta.

Devanti, A. P. (2018). Penyutradaraan Drama Musikal Hamlet. Kajian Sastraw, Teater Dan Sinema, 15(1), 111.

Kholid, D. M. (2016). Peranan Musik dalam Teater. Jurnal Ritme, 2(1), 17.

Manggala, Y. (2015). Komposisi Musik Romantika Kehidupan Untuk Ansambel Campuran.

Margono, S. 2003. Metodologi Penelitian Pendidikan. .Jakarta: Rineka Cipta

Nugraha, D. A. (2013). Analisis Struktur Komposisi dan Fungsi Musik Bregada Dhaeng di Keratin Kasultanan Yogyakarta.

Pardede, M. F. (2018). Nilai Pendidikan Karakter Dala drama Musikal mate mangkar Untuk Materi Pembelajaran Wawasan Seni Budaya Siswa Tingkat
SMP. Institut Seni Indonesia Yogyakarta.

Pramudya, N. A. (2019). Penciptaan Karya Komposisi Musik Sebagai Sebuah Penyampaian Makna Pengalaman Empiris Menjadi Sebuah Mahakarya. Jurnal Ilnstitut Seni Indonesia Surakarta, 17(1), 1423.

Prastyo, A. B. (2018). Garap Musik Teater Janggleng dalam Karya Kelir Disparta Jatisrono Wonogiri. Institut Seni Indonesia Surakarta.

Sapentri, E. (2017). Male Gaze dan Pengaruhnya Terhadap Representasi Perempuan dalam Lukisan " Realis Surealis " Karya Zaenal Arifin. Journal of Urban Society's Arts, 4(1), 29-35.

Shaleha, R. R. A. (2019). Do Re Mi : Psikologi , Musik, dan Budaya Do Re Mi : Psychology, Music, and Culture. Jurnal Buletin Psikologi, 27(1), 43-51. https://doi.org/10.22146/buletinpsi kologi.37152

Suryanto, E., Waluyo, B., \& Suyitno. (2016). Kajian dan Apresiasi Drama. Jurnal Universitas Sebelas Maret, 249-264.

Syahbandi, R., Mering, A., \& Silaban, C. Y. (n.d.). Studi Proses Penciptaan Karya Musik oleh Mahasiswa Seni Tari dan Musik. Jurnal Untan Pontianak, 1-8.

Wafa MU. (2020). Kreasi-Musik-Teknologi ? . Semarang: Pendidikan Seni Drama Tari dan Musik Unnes; 2020. 
Najwa Leonita Darussalam / Jurnal Seni Musik (10) (2) 